\title{
Skye Terrier
}

National Cancer Institute

\section{Source}

National Cancer Institute. Skye Terrier. NCI Thesaurus. Code C53731.

The Skye Terrier is a long and low terrier. Its undercoat is soft but its outer coat is long, hard, and straight. The colors of its coat are either gray-blue, dove or cream, always with black ears. A small amount of white may be found on the chest. The hair shields and protects the eyes and forehead. It has either upright or falling-down ears (although, falling-down ears are rare). Its tail is pendent and never curled. The hare-like feet are long and large, pointing straight forward. Height: 10 inches $(25.5 \mathrm{~cm}$.) Average Weight: 25 pounds (11.5 kg.) 